\section{AB1293 INCIDENCE OF SACROILITIS IN INFLAMMATORY BOWEL DISEASE: A SIGNLE-CENTRE STUDY FROM TIANJIN, CHINA}

D. Xiaoyan ${ }^{1}$, L. ling ${ }^{2} .{ }^{1}$ Master of Traditional Chinese Medicine, Tianjin University of Traditional Chinese Medicine; ${ }^{2}$ Department of rheumatology, Tianjin Union Medical Center, Tianjin, China

Background: Time trend studies have shown a rising incidence and prevalence of inflammatory bowel diseases (IBD) in China. IBD is a complex disease, which can present with a large number of extraintestinal manifestations (EIMs), such as skin, eye and joint lesions. Among these EIMs, spinal involvement is often silent and do not correlate with IBD activity. So the prevalence of spinal involvement in IBD is poorly understood.

Objectives: To estimate the incidence of sacroilitis and other extraintestinal complaints among patients with IBD in Tianjin Union Medical Centre.

Methods: From September 2017 to January 2018, for all patients who came to our hospital do endoscopic examination, we picked out patients who had a diagnosis of IBD (include ulcerative colitis, crohn's disease and colitis). All IBD patients who agreed to participate in the study completed a questionnaire. To investigate the incidence of spondyloarthritis, part of patients took screening test. Radiologic examination of pelvic to screen sacroilitis, blood sample to test erythrocyte sedimentation(ESR), C-reactive protein(CRP) and human leukocyte antigen B27 (HLA-B 27 ).

Results: 87 patients were enrolled; $93.1 \%$ had ulcerative colitis (UC), $1.1 \%$ had Crohn's disease (CD), and $5.7 \%$ had colitis. Among them, $54 \%$ were female. The mean age of onset in female and male was 47.6 years (range from 28 to 81 ) and 41.3 years (range from 18 to 72 ) respectively. Of the 87 patients, 56 patients $(64.4 \%)$ had a history of articular pain, some of which were involved in axial articular (45/56), peripheral articular (2/56), and both axial and peripheral articular (9/ 56). 20 patients $(22.98 \%)$ had history of enthesitis (e.g. plantar fasciitis, tendinitis achillea, anterior chest wall pain). 4 patients $(4.6 \%$ ) had history of skin impairment (e.g. nodule erythema, psoriasis, uticaria). 6 patients (6.9\%) had history of ocular lesions (e.g. red eye, sore eye, epipephysitis, cataract, vitreous opacity). 5 patients $(5.7 \%)$ had oral ulcer. 3 patients had family history of gastrointestinal disease ( 2 bowel cancer, 1 UC). 25 patients conducted radiologic examination of pelvic (14 X-ray, $10 \mathrm{CTs}$ and $1 \mathrm{MR}) .8$ patients (32\%) revealed sacroiliitis. Among these 8 patients, 2 of them showed asymptomatic radiological involvement of sacroiliac joint. The texts of $\mathrm{HLA}-\mathrm{B}_{27}$ were performed in 29 patients (include patients who conducted radiologic examination of peivic), and all revealed negative results. 52 patients tested ESR and CRP, 30 patients showed higher results than normal bias.

Conclusions: This study displayed the incidence of sacroilitis, among patients with IBD in our centre, it showed that patients with IBD have a higher incidence of sacroilitis. In order to evaluate the patients comprehensively, IBD patients with articular pain should be evaluated by rheumatologist. Besides, among our patients with IBD, the occurance of $\mathrm{HLA}-\mathrm{B}_{27}$ is low, and there were no correlation between IBD activity and articular symptoms or inflammatory indicators.

\section{REFERENCE:}

[1] inflammatory bowel disease, extraintestinal manifestations, sacroiliitis

Disclosure of Interest: None declared

DOI: 10.1136/annrheumdis-2018-eular.6588

\section{AB1294 IMPACT OF WORK STATUS ON HEALTH-RELATED QUALITY OF LIFE (HRQOL) IN RA}

E. Alemao ${ }^{1}$, A. Boonen ${ }^{2}$, Z. Guo ${ }^{1}$, C. lannaccone ${ }^{3}$, M. Frits ${ }^{3}$, M.E. Weinblatt ${ }^{3}$, N. A. Shadick ${ }^{3} .{ }^{1}$ Bristol-Myers Squibb, Princeton, USA; ${ }^{2}$ Maastricht University Medical Centre, Maastricht, Netherlands; ${ }^{3}$ Brigham and Women's Hospital, Boston, USA

Background: Compared to the general population, RA patients (pts) are less likely to be employed and have lower HRQoL. ${ }^{1,2}$ However, data on impact of work status on HRQoL in RA pts are limited.

Objectives: Evaluate association between work status and HRQoL in RA pts.

Methods: We analysed data from adult pts enrolled in a large sequential RA registry. Physicians assessed pt demographics, clinical characteristics, disease activity and laboratory parameters at baseline (BL) and then annually. Follow-up questionnaires to assess pt-reported outcomes were administered every 6 months and included HRQoL measures (12-Item Short-Form Health Survey physical and mental component summary [SF-12 PCS, MCS], EuroQoL-5 Dimension [EQ-5D]) and work status; higher score indicates better health for all $3 \mathrm{HRQoL}$ measures. General linear mixed models with repeated measures were used for SF-12 analysis and finite mixture models for the EQ-5D analysis, controlling for BL covariates.

Results: A total of 974 RA pts with HRQoL information were included: $49.3 \%$ $(n=480)$ 'employed for pay', 38.9\% ( $n=379)$ 'employed not for pay' (retired, homemaker or student), $11.8 \%$ ( $n=115)$ 'not employed or on disability'. Pts employed for pay were younger and had lower disease activity compared with other groups (table 1). Compared with pts 'not employed or on disability', pts employed had significantly higher PCS (mean [SE] 7.17 [0.82]; $p<0.001$ ), MCS (5.39 [0.80]; $p<0.001)$ and EQ-5D (0.48 [0.16]; $p=0.0031)$ scores. Similar results were observed comparing pts 'employed not for pay' to pts 'not employed or on disability' (Table 2).

Abstract AB1294 - Table 1. BL Characteristics by Work Status

\begin{tabular}{|c|c|c|c|}
\hline Variable & $\begin{array}{l}\text { Employed } \\
(n=480)\end{array}$ & $\begin{array}{c}\text { Employed not for } \\
\text { pay }^{\star} \\
(n=379)\end{array}$ & $\begin{array}{c}\text { Not employed or } \\
\text { disabled } \\
(n=115)\end{array}$ \\
\hline Age, years & $\begin{array}{l}52.66 \\
(0.53)\end{array}$ & $66.21(0.60)$ & $56.69(0.90)$ \\
\hline RA disease duration, years & $\begin{array}{l}12.78 \\
(0.46)\end{array}$ & $18.40(0.67)$ & $17.09(1.05)$ \\
\hline DAS28 (CRP) & $\begin{array}{l}2.94 \\
(0.07)\end{array}$ & $3.51(0.08)$ & $4.03(0.16)$ \\
\hline Multidimensional $\mathrm{HAQ}$ & $\begin{array}{l}0.36 \\
(0.02)\end{array}$ & $0.60(0.03)$ & $0.99(0.05)$ \\
\hline SDAI & $\begin{array}{l}13.34 \\
(0.65)\end{array}$ & $18.83(0.89)$ & $24.75(1.84)$ \\
\hline TJC (28 joints) & $\begin{array}{c}7.47 \\
(0.47)\end{array}$ & $11.67(0.66)$ & $14.64(1.41)$ \\
\hline Female, n (\%) & $\begin{array}{c}395 \\
(82.29)\end{array}$ & $310(81.79)$ & $106(92.17)$ \\
\hline Biologic DMARDs, n (\%) & $\begin{array}{c}239 \\
(49.79)\end{array}$ & $174(45.91)$ & $64(55.65)$ \\
\hline Seropositive, $n(\%)$ & $\begin{array}{c}230 \\
(60.53)\end{array}$ & $211(67.2)$ & $59(64.13)$ \\
\hline $\begin{array}{l}\text { Household income }<\$ 50,000 \text {, } \\
n(\%)\end{array}$ & $86(18.90)$ & $146(45.63)$ & $65(60.74)$ \\
\hline $\begin{array}{l}\text { Household income } \geq \$ 50,000 \text {, } \\
\mathrm{n}(\%)\end{array}$ & $\begin{array}{c}369 \\
(81.10)\end{array}$ & $174(54.38)$ & $42(39.25)$ \\
\hline $\begin{array}{l}\text { Stopped work due to RA, n } \\
(\%)\end{array}$ & $9(1.88)$ & $101(27.15)$ & $80(70.18)$ \\
\hline
\end{tabular}

Data are mean (SE) unless otherwise indicated; *Retired, homemaker or student

Abstract AB1294 - Table 2. Multivariate Analysis of Impact of Work Status on HRQoL

\begin{tabular}{|c|c|c|c|c|c|c|}
\hline \multirow[b]{2}{*}{ Effect } & \multicolumn{2}{|c|}{$\begin{array}{l}\text { SF-12 PCS general } \\
\text { linear model }\end{array}$} & \multicolumn{2}{|c|}{$\begin{array}{l}\text { SF-12 MCS general } \\
\text { linear model }\end{array}$} & \multicolumn{2}{|c|}{$\begin{array}{c}\text { EQ-5D mixture } \\
\text { model }\end{array}$} \\
\hline & $\begin{array}{l}\text { Estimate } \\
\text { (SE) }\end{array}$ & $\operatorname{Pr}>|t|$ & $\begin{array}{l}\text { Estimate } \\
\text { (SE) }\end{array}$ & $\operatorname{Pr}>|t|$ & $\begin{array}{l}\text { Estimate } \\
\text { (SE) }\end{array}$ & $\operatorname{Pr}>|t|$ \\
\hline $\begin{array}{l}\text { Employed for pay (vs } \\
\text { not employed or } \\
\text { disabled) }\end{array}$ & $\begin{array}{c}7.17 \\
(0.82)\end{array}$ & $<0.0001$ & $\begin{array}{c}5.39 \\
(0.80)\end{array}$ & $<0.0001$ & $\begin{array}{c}0.48 \\
(0.16)\end{array}$ & 0.0031 \\
\hline $\begin{array}{l}\text { Employed not for pay } \\
\text { (vs not employed or } \\
\text { disabled) }\end{array}$ & $\begin{array}{c}3.75 \\
(0.82)\end{array}$ & $<0.0001$ & $\begin{array}{c}6.78 \\
(0.81)\end{array}$ & $<0.0001$ & $\begin{array}{c}0.42 \\
(0.16)\end{array}$ & 0.0104 \\
\hline $\begin{array}{l}\text { Income }<\$ 50,000 / \text { year } \\
\text { (vs } \geq \$ 50,000 / \text { year) }\end{array}$ & $\begin{array}{l}-1.04 \\
(0.56)\end{array}$ & 0.0655 & $\begin{array}{l}-2.56 \\
(0.55)\end{array}$ & $<0.0001$ & $\begin{array}{l}-0.19 \\
(0.12)\end{array}$ & 0.1084 \\
\hline
\end{tabular}

Other covariates included in the model were age, sex, disease duration, disease activity, acute-phase reactant (CRP), BMI, serostatus and time points

Conclusions: Work status and household income in RA are independently associated with HRQoL. More studies are needed to evaluate impact of work on changes in HRQoL in RA pts.

REFERENCES:

[1] Uhlig T, et al. J Rheumatol 2007;34:1241-7.

[2] Chorus AM, et al. Ann Rheum Dis 2003;62:1178-84.

Disclosure of Interest: E. Alemao Shareholder of: Bristol-Myers Squibb, Employee of: Bristol-Myers Squibb, A. Boonen: None declared, Z. Guo Shareholder of: Bristol-Myers Squibb, Employee of: Bristol-Myers Squibb, C. lannaccone: None declared, M. Frits: None declared, M. Weinblatt Grant/research support from: Amgen, Bristol-Myers Squibb, Crescendo Bioscience, Sanofi, Consultant for: AbbVie, Amgen, Bristol-Myers Squibb, Crescendo Bioscience, Lilly, Merck, Novartis, Pfizer, Roche, Samsung, N. Shadick Grant/research support from: Amgen, BRASS registry, Bristol-Myers Squibb, Mallinckrodt, Consultant for: Bristol-Myers Squibb

DOI: 10.1136/annrheumdis-2018-eular.2506 
Abstract AB1298 - Table 1. Prevalence of rheumatic diseases distributed by city

\begin{tabular}{|c|c|c|c|c|c|c|c|c|}
\hline & Men & Women & Bogotá & Medellín & Cali & B/quilla & $\begin{array}{c}\mathrm{B} / \\
\text { manga }\end{array}$ & Cúcuta \\
\hline $\begin{array}{l}\text { Non-specific } \\
\text { musculoskeletal disease }\end{array}$ & $15,99 \%$ & $16,50 \%$ & $14,67 \%$ & $14,64 \%$ & $17,16 \%$ & $21,88 \%$ & $20,43 \%$ & $26,15 \%$ \\
\hline Osteoarthritis & $11,13 \%$ & $20,31 \%$ & $17,98 \%$ & $17,07 \%$ & $11,06 \%$ & $10,60 \%$ & $14,22 \%$ & $16,78 \%$ \\
\hline Mechanical Low Back pain & $8,58 \%$ & $8,19 \%$ & $10,15 \%$ & $4,39 \%$ & $5,23 \%$ & $11,91 \%$ & $3,82 \%$ & $11,68 \%$ \\
\hline Rheumatoid arthritis & $0,95 \%$ & $2,89 \%$ & $2,60 \%$ & $0,69 \%$ & $2,22 \%$ & $1,19 \%$ & $0,80 \%$ & $1,04 \%$ \\
\hline $\begin{array}{l}\text { Rheumatic Regional Pain } \\
\text { Syndromes }\end{array}$ & $0,96 \%$ & $1,96 \%$ & $2,67 \%$ & $0,32 \%$ & $0,10 \%$ & $0,26 \%$ & $0,23 \%$ & - \\
\hline Fibromyalgia & $0,05 \%$ & $2,27 \%$ & $1,29 \%$ & $1,09 \%$ & $1,41 \%$ & $1,07 \%$ & $0,44 \%$ & $1,34 \%$ \\
\hline $\begin{array}{l}\text { Inflammatory Low Back } \\
\text { Pain }\end{array}$ & $1,08 \%$ & $0,72 \%$ & $1,29 \%$ & $0,49 \%$ & $0,47 \%$ & $0,43 \%$ & - & $0,83 \%$ \\
\hline Gout & $1,28 \%$ & $0,05 \%$ & $1,09 \%$ & - & - & - & $0,27 \%$ & $1,34 \%$ \\
\hline $\begin{array}{l}\text { Undifferentiated } \\
\text { spondyloarthritis }\end{array}$ & $0,42 \%$ & $0,62 \%$ & $0,82 \%$ & - & $0,37 \%$ & $0,38 \%$ & - & $0,29 \%$ \\
\hline Ankylosing spondylitis & $0,96 \%$ & $0,08 \%$ & $0,08 \%$ & $2,20 \%$ & $0,47 \%$ & - & - & - \\
\hline Undifferentiated arthritis & $0,14 \%$ & $0,46 \%$ & $0,09 \%$ & $0,56 \%$ & $0,19 \%$ & $0,48 \%$ & $0,78 \%$ & $1,97 \%$ \\
\hline $\begin{array}{l}\text { Systemic lupus } \\
\text { erythematosus }\end{array}$ & - & $0,41 \%$ & $0,22 \%$ & $0,29 \%$ & $0,16 \%$ & $0,36 \%$ & - & - \\
\hline Sjogren's syndrome & $0,04 \%$ & $0,28 \%$ & $0,24 \%$ & - & $0,16 \%$ & $0,23 \%$ & - & - \\
\hline Systemic sclerosis & - & $0,04 \%$ & $0,04 \%$ & - & - & - & - & - \\
\hline
\end{tabular}

\section{AB1295 ASSOCIATION OF SHARED EPITOPE AND POOR PROGNOSTIC FACTORS IN RA}

E. Alemao ${ }^{1}$, Z. Guo ${ }^{1}$, J. Bryson ${ }^{1}$, C. lannaccone ${ }^{2}$, M. Frits ${ }^{2}$, N.A. Shadick ${ }^{2}$, M. E. Weinblatt ${ }^{2}{ }^{1}$ Bristol-Myers Squibb, Princeton; ${ }^{2}$ Brigham and Women's Hospital, Boston, USA

Background: Strong genetic association has been reported between RA and human leukocyte antigen (HLA) regions, particularly HLA-DRB1 alleles with the shared epitope (SE). SE alleles are associated with seropositivity, erosions and higher disease activity (DA) in RA.

Objectives: To evaluate the association between SE alleles and the presence of multiple poor prognostic factors (PPFs) of seropositive (anti-citrullinated protein antibody [ACPA] and/or RF) and erosive RA; as well as changes in DA.

Methods: We analysed patients (pts) enrolled in a large sequential RA registry established in 2003; most had established RA and annual clinical evaluations. Pts with baseline (BL) data on SE status were included. A commercially available kit (Qiagen, USA) was used for HLA genotyping. HLA-DRB1 serotypes were assessed from DNA sequences using allele-specific polymerase chain reaction methods and categorised as pts with no, 1 or 2 SE alleles. Changes from BL were compared in pts with vs without SE alleles. The association of multiple PPFs and SE status was evaluated using multinomial logistic models. The association between change in DA and SE status was analysed using linear regression models with age, sex, disease duration (DD), co-morbidities and biologic DMARDs as covariates.

Abstract AB1295 - Table 1. Baseline Characteristics by SE status

\begin{tabular}{lccc}
\hline & $\begin{array}{c}\text { No SE alleles } \\
(\mathbf{n = 2 4 1 )}\end{array}$ & $\begin{array}{c}\text { 1 SE allele } \\
(\mathbf{n}=\mathbf{2 7 5})\end{array}$ & $\begin{array}{c}\text { 2 SE alleles } \\
(\mathbf{n}=\mathbf{1 7 3})\end{array}$ \\
\hline Mean (SD) age, years & $57.7(13.6)$ & $58(13.9)$ & $57.8(13.6)$ \\
Female, $\mathbf{n}$ (\%) & $202(83.8)$ & $219(79.6)$ & $141(81.5)$ \\
Mean (SD) RA duration, years & $12.9(12.1)$ & $17(13.3)$ & $16.1(12.2)$ \\
Biologic DMARDs, $\mathbf{n}(\%)$ & $83(34.4)$ & $145(52.7)$ & $83(48.0)$ \\
ACPA+, $\mathbf{n}$ (\%) & $118(49.0)$ & $196(71.3)$ & $137(79.2)$ \\
Erosions, $\mathbf{n}(\%)$ & $116(48.1)$ & $168(61.1)$ & $114(65.9)$ \\
RF+, $\mathbf{n}(\%)$ & $120(49.8)$ & $195(70.9)$ & $128(74.0)$ \\
Double positive, $\mathbf{n}(\%)$ & $100(41.5)$ & $174(63.3)$ & $121(69.9)$ \\
DAS28 (CRP), mean (SD) & $3.8(1.5)$ & $4.2(1.6)$ & $4.3(1.6)$ \\
\hline
\end{tabular}

Abstract AB1295 - Table 2. Multivariate Analysis of Impact of SE Status on Change in DA

\begin{tabular}{|c|c|c|c|c|c|c|}
\hline & \multicolumn{2}{|c|}{ DAS28 (CRP) model } & \multicolumn{2}{|c|}{ CDAl model } & \multicolumn{2}{|c|}{ SDAI model } \\
\hline & Coefficient & $\begin{array}{c}\mathbf{p} \\
\text { value }\end{array}$ & Coefficient & $\begin{array}{c}\mathbf{p} \\
\text { value }\end{array}$ & Coefficient & $\begin{array}{c}\mathrm{p} \\
\text { value }\end{array}$ \\
\hline $\begin{array}{l}1 \text { or } 2 \text { SE alleles } \\
\text { (vs no SE) }\end{array}$ & 0.24 & 0.031 & 2.71 & 0.027 & 3.25 & 0.013 \\
\hline Baseline DA & -0.41 & $<0.001$ & -0.46 & $<0.001$ & -0.48 & $<0.001$ \\
\hline Age, years & 0.01 & 0.271 & 0.04 & 0.367 & 0.04 & 0.406 \\
\hline Female (vs male) & 0.11 & 0.435 & 2.52 & 0.099 & 2.12 & 0.198 \\
\hline $\begin{array}{l}\text { No. of co- } \\
\text { morbidities }\end{array}$ & 0.11 & 0.003 & 1.25 & 0.003 & 1.42 & 0.002 \\
\hline $\begin{array}{l}\text { Biologic DMARD } \\
\text { (yes vs no) }\end{array}$ & 0.41 & $<0.001$ & 3.79 & 0.002 & 4.09 & 0.001 \\
\hline $\begin{array}{l}\text { Adjusted R- } \\
\text { square }\end{array}$ & \multicolumn{2}{|c|}{0.23} & \multicolumn{2}{|l|}{0.27} & \multicolumn{2}{|l|}{0.29} \\
\hline
\end{tabular}

Results: Of 689 RA pts included, no, 1 and 2 SE alleles were reported in 241 (35.0\%), 275 (40.0\%) and 173 (25.1\%) pts, respectively. At BL, pts with SE alleles (vs no SE) were more likely to have PPFs, and had longer DD and higher DA (table 1). The odds ratio (OR) for seropositive erosive RA in pts with 2 and $1 \mathrm{SE}$ alleles (vs no SE) was $5.44(95 \% \mathrm{Cl} 2.39,12.39)$ and $2.87(1.32,6.23$; Fig), respectively. The OR for double seropositivity in pts with 2 and $1 \mathrm{SE}$ alleles (vs no SE) was $4.27(95 \% \mathrm{Cl} 2.51,7.28)$ and $2.56(1.66,3.94)$, respectively. A total o 551 pts had DA measures at BL and 1 year follow-up. After controlling for BL covariates, pts with SE (vs no SE) had an average increase in DAS28 (CRP) of $0.24(p=0.031)$, CDAl of 2.71 ( $p=0.027)$ and SDAI of 3.25 ( $p=0.013$; Table 2$)$.

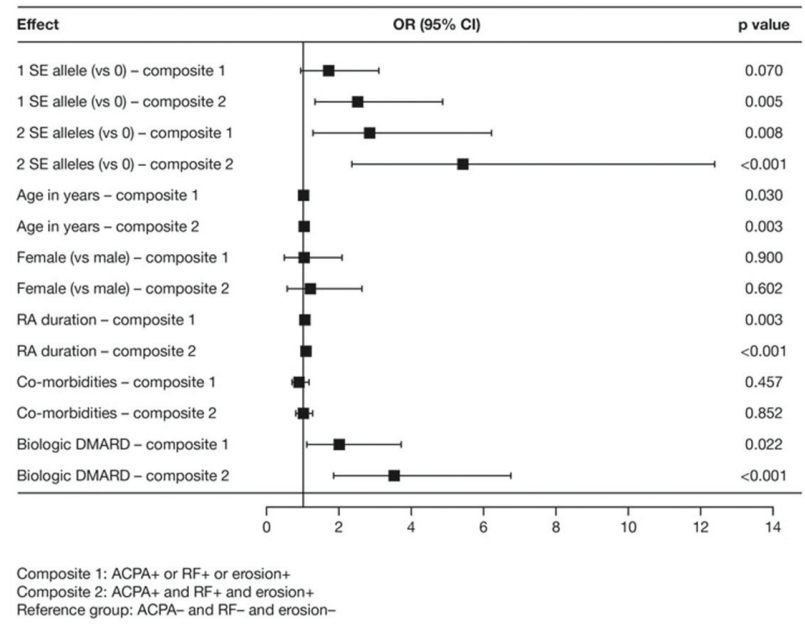

Abstract AB1295 - Figure 1. Multinomial Model for Multiple PPFs (Seropositive and Erosions)

Conclusions: Pts with (vs without) SE alleles are more likely to have multiple PPFs; pts with 2 SE alleles are 5 times more likely to be seropositive with erosive RA and 4 times more likely to be double positive. Pts with (vs without) SE alleles also experienced an increase in DA over time with standard-of-care treatment.

Disclosure of Interest: E. Alemao Shareholder of: Bristol-Myers Squibb, Employee of: Bristol-Myers Squibb, Z. Guo Employee of: Bristol-Myers Squibb, J. Bryson Shareholder of: Bristol-Myers Squibb, Employee of: Bristol-Myers Squibb, C. Iannaccone: None declared, M. Frits: None declared, N. Shadick Grant/ research support from: BRASS registry, Amgen, Bristol-Myers Squibb, and Mallinckrodt, Consultant for: Bristol-Myers Squibb, M. Weinblatt Grant/research support from: Bristol-Myers Squibb, Amgen, Crescendo Bioscience, Sanofi, Consultant for: Bristol-Myers Squibb, Amgen, Crescendo Bioscience, AbbVie, Eli Lilly, Pfizer, Roche, Merck, Samsung, Novartis

DOI: 10.1136/annrheumdis-2018-eular.1657 

SAFETY IN RHEUMATOID ARTHRITIS

E. Chamizo ${ }^{1}$, E. González ${ }^{2}$, C. Carrasco ${ }^{1}$, S. Rojas ${ }^{1}$, J.J. Aznar ${ }^{1}$, P. Dorado ${ }^{2}$, A. Llerena ${ }^{2} .{ }^{1}$ Rheumatology, Hospital Mérida and CHU Badajoz, Mérida; ${ }^{2} \mathrm{CICAB}$, CHU de Badajoz, Badajoz, Spain

Background: Methotrexate (MTX) is the DMARD of choice in the treatment of rheumatoid arthritis (RA). Despite an acceptable efficacy, its use is limited by side effects. The most known adverse events (AE) are gastrointestinal, hepatic, and haematological.

Objectives: To study the effect of clinical characteristics and of different genetic single nucleotide polymorphisms (SNPs) related to the transport and metabolic pathways of MTX, on the toxicity of this compound, in a cohort of RA patients treated with MTX in monotherapy.

Methods: Observational study. Toxicity was defined as the occurrence of $A E$, global and of haematological, hepatic, and gastrointestinal nature. Factors under study: SNPs of transport (ABCB1 C3435T), glutamation (GGH T16C and FPGS G2782A), transmethylation (MTHFR C677T and MTHFR A1298C) and adenosine (AMPD1 C34T, ADA A534G, ITPA C94A). The association between SNPs and MTX toxicity was analysed using logistic regression models, assessing allele independence (Hardy-Weinberg equilibrium) and interaction with sex. Different models of inheritance of SNPs were analysed. The models were adjusted by the characteristics of the patient, of disease and of treatment. The haplotypes of the MTHFR SNPs (C677T and A1298C) were also analysed.

Results: Bivariate analysis showed that $\mathrm{AE}$, globally considered, are related to lower age at diagnosis $(\mathrm{OR}=0.98)$, female sex $(\mathrm{OR}=1.95)$, disease activity $(\mathrm{OR}=1.38)$, extra-articular manifestations $(\mathrm{OR}=1.84)$ and comorbidity $(\mathrm{OR}=1.14)$. For the SNPs, the $A / G$ genotype of the ADA A534G decreases the probability of $A E(O R=0.55)$; the $G / G$ of the ADA A534G increases the hepatic $A E(O R=10.1)$ and the genotypes $C / T$ and $T / T$ of the $A B C B 1$ C3435T decrease the risk of haematological $\mathrm{AE}$

According to the adjusted analysis, the probability of global $A E$ increased with the $\mathrm{C} / \mathrm{T}$ genotypes of MTHFR C677T (OR=1.85) and $\mathrm{C} / \mathrm{C}$ of $\mathrm{GGH}$ T16C $(\mathrm{OR}=2.53)$ and decreased with the $\mathrm{A} / \mathrm{G}$ of ADA A534G $(\mathrm{OR}=0.49)$. Gastrointestinal AEs were less frequent in patients with $A / G$ genotype of $A D A A 534 G(O R=0.49)$ and in men with $\mathrm{G} / \mathrm{A}$ of FPGS $2782 \mathrm{GAc}(\mathrm{OR}=0.29)$. The $\mathrm{G} / \mathrm{G}$ genotype of the SNP ADA_534AG was associated with a significant increase in hepatic $A E(O R=12.7)$, which was also observed in men with the MTHFR A1298C (OR=8.34). The T allele of the $A B C B 1$ C3435T decreases the probability of haematological $A E$, especially in women $(\mathrm{OR}=0.06)$. All the effects were independent of the characteristics of patient, disease and treatment. The $\mathrm{C} / \mathrm{C}$ haplotype of the combination MTHFR C677T and MTHFR A1298C increases the probability of global $(\mathrm{OR}=4.35)$ and hepatic $\mathrm{AE}(\mathrm{OR}=11.9)$ in men, but not in women.

Conclusions: SNPs related to the transport and metabolism of MTX are associated with liver toxicity of MTX.

Disclosure of Interest: None declared

DOI: 10.1136/annrheumdis-2018-eular.3088

\section{AB1297 HIGH PREVALENCE OF SERONEGATIVE RHEUMATOID ARTHRITISIN A MAYA-YUCATECO INDIGENOUS POPULATION: A COHORT COMMUNITY-BASED STUDY}

F. Morales-Arango ${ }^{1}$, J.F. Moctezuma ${ }^{2}$, A. Loyola-Sanchez ${ }^{3}$, H. Garcia $^{4}$, E. AlvarezHernandez ${ }^{2}$, C. García ${ }^{2}$, J. Alvarez-Nemegyei ${ }^{5}$, J. Vazquez-Mellado ${ }^{2}$, H. AyoraManzano $^{6}$, G. Cruz-Martin ${ }^{7}$, D. Flores-Aguilar ${ }^{6}$, R. Pereira-Zaldivar ${ }^{8}$, M. ZarateDominguez ${ }^{8}$, M. Mendoza ${ }^{8}$, I. Pelaez-Ballestas ${ }^{2}$, on behalf of GLADERPO. ${ }^{1}$ Faculty of Medicine, Universidad Autonoma del Estado de Puebla, Puebla; ${ }^{2}$ Rheumatology Unit, Hospital General de Mexico, Mexico, Mexico; ${ }^{3}$ University of Calgary, Calgary, Canada; ${ }^{4}$ Private Practice, Cancún; ${ }^{5}$ Hospital Star Medica; ${ }^{6}$ Universidad Autonoma de Yucatan, Merida; ${ }^{7}$ Faculty of Medicine, Universidad Nacional Autonoma de Mexico, Mexico; ${ }^{8}$ Hospital General de Valladolid, Valladolid, Mexico

Background: Eighty percent of people living with rheumatoid arthritis (RA) are seropositive. Recent studies show that seronegative RA is associated with a more aggressive clinical presentation; however, this association has not been studied in indigenous populations.

Objectives: To compare the clinical and radiographic characteristics, functioning and quality of life in a group of Maya-Yucateco indigenous patients with RA, based on their seropositivity Rheumatoid Factor (RF- IgM).

Methods: A community-based cohort was formed in 2014 with the aim of detecting and performing a community intervention in a Mayan Municipality in Mexico. Patients who fulfilled ACR/EULAR criteria $1987 / 2010$ for RA were included and rheumatologists evaluated them every 3 months. All evaluations were conducted in the community with the support of trained translators and included: 1 . Clinical examinations. 2. Laboratories (i.e. RF, ESR, CRP). 3. Radiographic evaluations. 4. Functioning (HAQ-DI) and quality of life (EQ5D-3L) assessments. 5.
Pharmacological treatment. 6. Non-pharmacological treatment: individual and group exercises.

A quantitative comparative analysis was conducted by dividing the cohort in seropositive and seronegative and comparing all variables measured using a $\chi^{2}$; test, Student's $t$-test or Mann-Whitney $U$ test, as well as Kruskall-Wallis test for the non-parametric variables.

Results: Twenty eight of 430 participants were diagnosed with RA (1.8\%, Cl95\%; 1.2 to 2.6 ), for an incidence $0.72 \%$ (Cl95\% 0.3 to 1.2 ) in 4 years. Seventy-eight\% were women, the mean age was 53.9 years (standard deviation $(S D)=13.2$ ) and the level of education was on average 2 years (0-5.5).

We observed high prevalence of family history of rheumatic disease $(75 \%)$, exposure to woodstove $(96.1 \%)$, and a Chikungunya virus infection (10.7\%) and RF$(65.3 \%)$.

The treatment given was methotrexate in $64.2 \%$ as monotherapy, and $21.4 \%$ in combination therapy. NSAIDs were prescribed in $98.2 \%$. Prednisone was prescribed at low doses ( $<7.5 \mathrm{mg} /$ day) in $14.2 \%$.

The level of pain/discomfort assessed through EQ-5D3L dimension was significantly higher in the seropositive group in comparison with the seronegative group. No other differences were detected between these groups (see Table).

Abstract AB1297 - Table 1

\begin{tabular}{lccc}
\hline Variable & $\begin{array}{c}\text { Seronegative } \\
(\mathrm{n}=17) \mathrm{n}(\%)\end{array}$ & $\begin{array}{c}\text { Seropositive } \\
(\mathrm{n}=9) \\
\mathrm{n}(\%)\end{array}$ & $\mathrm{p}$ value \\
\hline Family history of RD* & $16(94.1)$ & $5(55.5)$ & 0.01 \\
Work & $16(94.1)$ & $6(66.6)$ & 0.06 \\
DAS28, median (IQR) & $3.7(2.9-3.9)$ & $3.9(3.3-4.4)$ & - \\
Van der Heijde- modified Sharp score, mean (SD) & $93.4(13.0)$ & $110.2(7.8)$ & - \\
EQ5D-3L & & & 0.04 \\
Pain/discomfort & & & \\
No problems & $2(12.5)$ & $1(11.1)$ & \\
Some problems & $11(68.7)$ & $2(22.2)$ & \\
Extreme problems & $3(18.7)$ & $6(66.6)$ & \\
Disability (HAQ>0.8) & $3(17.6)$ & $4(44.4)$ & 0.1 \\
\hline
\end{tabular}

${ }^{*} \mathrm{p} \leq 0.04$

RD rheumatic diseases; DAS-28 disease activity score; HAQ Health Assement Questionnaire.

Conclusions: The prevalence with negative RF is high in the community studied however, no differences were observed in the variables studied, except in pain.

Acknowledgements: Funding: CONACYT-233777

Disclosure of Interest: None declared

DOI: 10.1136/annrheumdis-2018-eular.5944

\section{AB1298 PREVALENCE OF RHEUMATIC DISEASES IN COLOMBIA BY CITY}

J. Londono ${ }^{1}$, F.M. Cuervo ${ }^{1}$, J.C. Rueda ${ }^{1}$, E.L. Saldarriaga ${ }^{1}$, I. Angarita ${ }^{1}$, I. Peláez ${ }^{2}$, E. Forero ${ }^{3}$, J. Ramirez ${ }^{4}$, C. Toro ${ }^{4}$, A. Santos ${ }^{1} .{ }^{1}$ Grupo de investigación Espondiloartropatias, Universidad de La Sabana-Hospital Militar Central, Chía, Colombia: ${ }^{2}$ Hospital General de México, Ciudad de México, Mexico; ${ }^{3}$ Universidad del Norte, Barranquilla; ${ }^{4}$ Asociación Colombiana de Reumatología, Bogotá, Colombia

Background: Knowledge of the prevalence of rheumatic diseases allows us to design public health strategies for their comprehensive care and reduction of the costs derived from the potential complications of these diseases.

Objectives: To describe and compare the prevalence of rheumatic disease between six cities from Colombia.

Methods: The study was developed according the COPCORD epidemiological strategy designed for the identification, prevention and control of rheumatic diseases in developing countries.

A cross-sectional analytical study including individuals older than 18 years was designed with a calculated sample size of 6528 people (2336 from Bogotá, 1220 from Medellín and Cali each, 746 from Barranquilla, from Bucaramanga and Cúcuta each one). Prevalence of each rheumatic disease was compared between the evaluated cities from Colombia.

Results: A total of 6693 individuals from six cities of Colombia were evaluated. The average age was $46,40 \pm 18,35$ and $4283(64 \%)$ individuals were women. The cities with the highest frequency of positive COPCORD population were Bogotá $36,6 \%(n=1813)$, Cali 19,1\% $(n=945)$ and Medellín 15,9\% $(n=789)$. Abstract AB1298 - Figure 1

The majority of musculoskeletal pain manifested by the population correspond to non-specific muscular discomfort (MMNE). Osteoarthritis (OA) is the most prevalent rheumatic disease $(10,81 \%, 95 \% \mathrm{Cl}, 9,68-12,06 \%)$. Mechanical low back pain was the most frequent disease in Barranquilla, with a prevalence of $11,91 \%$ mainly in men $15,9 \%(95 \% \mathrm{Cl}, 11,24-21,92 \%)$. Regarding to rheumatoid arthritis (RA) it was more prevalent in women, between 40 and 59 years. It was found to 
be more prevalent in Bogotá $(2,8 \%, 95 \% \mathrm{Cl}, 1,8 \%-4,1 \%)$, Cali $(4,2 \%, 95 \% \mathrm{Cl}$, $2,4-7,3 \%)$ and Barranquilla (1,5\%, 95\% Cl, 0,65-3,23\%). Table 1.

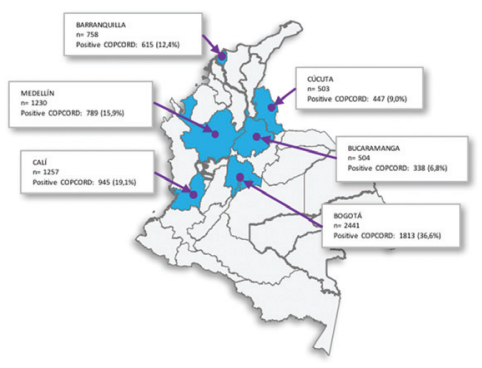

Abstract AB1298 - Figure 1. Diagram of cities surveyed as COPCORD* positive

COPCORD*: Community Oriented Program for Control of Rheumatic Diseases Conclusions: Prevalence of rheumatic diseases is higher in the cities of Bogotá, Cali and Medellin. In Bogotá, Cali and Barranquilla, RA was more prevalent. Low back pain was found to be more prevalent in Barranquilla. The hypothesis is that ethnic diversity of Colombia could explain the difference in prevalence of the rheumatic disease among separate regions.

Disclosure of Interest: None declared

DOI: 10.1136/annrheumdis-2018-eular.4356

\section{AB1299 FUNCTIONAL CAPACITY MEASURED BY HAQ IN PATIENTS WITH RHEUMATIC DISEASES IN COLOMBIA}

F.M. Cuervo ${ }^{1}$, A. Santos ${ }^{1}$, E.L. Saldarriaga ${ }^{1}$, J.C. Rueda ${ }^{1}$, I. Angarita ${ }^{1}$, J. Ballesteros ${ }^{1}$, I. Peláez ${ }^{2}$, E. Forero ${ }^{3}$, J. Ramirez ${ }^{4}$, J. Londono ${ }^{1} .{ }^{1}$ Grupo de investigación Espondiloartropatias, Universidad de La Sabana-Hospital Militar Central, Chía, Colombia; ${ }^{2}$ Hospital General de México, Ciudad de México, Mexico; ${ }^{3}$ Universidad del Norte, Barranquilla; ${ }^{4}$ Asociación Colombiana de Reumatología, Bogotá, Colombia

Background: Functional capacity is an important indicator of quality of life that is affected in different pathologies and is susceptible to intervention in early stages once it is recognised. In rheumatic diseases, functional limitation has a great impact that is evidenced by multiple degrees of long-term disability.

Objectives: To evaluate the functional capacity in different rheumatic diseases by $\mathrm{HAQ}$ (Health Assessment Questionnaire) instrument.

Methods: In the context of the prevalence study of rheumatic disease in Colombia, the assessment of functional capacity was measured by using the HAQ score, where functional limitation is scored in a range from 0 to 3 points according to the severity of limitation. The major functional limitation is scored 3 and not limitation 0 .

A total of 4020 individuals answered the questionnaire.

Results: Patients with rheumatic diseases $(n=2274)$ reported a greater degree of limitation compared with disease-free people $(n=1104)$ or non-rheumatic patients $(n=642) \quad(p<0,001)$. Especially patients with rheumatoid arthritis $(R A)$ had the worst score $(0.88 \pm 0,72)$ compared to $0.06 \pm 0,22$ and $0.01 \pm 0,14$ of the population with non-rheumatic and healthy population, respectively $(p<0.001)$. The HAQ score in the remaining diseases was $0,67(S D \pm 0,62)$ for systemic lupus erythematosus (SLE), followed by patients with osteoarthrosis $(\mathrm{OA}) 0,59(\mathrm{SD} \pm 0,58)$, fibromyalgia (FM) 0,56 (SD $\pm 0,57)$ and spondylarthritis $(S p A)$ 0,52 (SD $\pm 0,43)$. Abstract AB1299-Figure 1

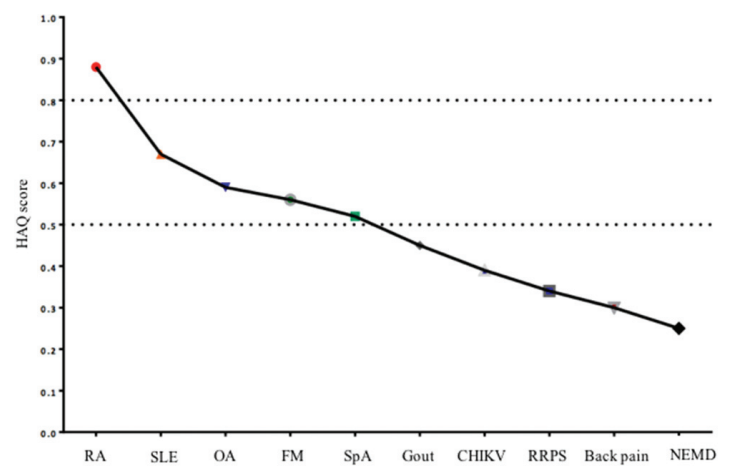

Abstract AB1299 - Figure 1. Functional capacity of patients with rheumatic diseases
Functional capacity evaluated by $\mathrm{HAQ}$, the points represent the mean of the instrument. * RA: Rheumatoid Arthritis; SLE: Systemic Lupus Erythematosus; OA: Osteoarthritis; FM: Fibromyalgia; SpA: Spondyloarthritis; CHIKV: Chikungunya fever; RRPS: Rheumatic Regional Pain Syndromes (Rotator cuff tendinopathy, shoulder bicipital tendinopathy, lateral and medial medial epicondylalgia, Quervain's tendinopathy, carpal tunnel syndrome, Dupuytren's contracture, trochanteric syndrome, anserine bursitis, achilles tendonopathy, plantar talalgia); NEMD: non-specific musculoskeletal disease.

Conclusions: In comparison with disease-free population and non-rheumatic patients, the rheumatic patients had a lower functional capacity measured by HAQ. Patients with RA had more disability followed by patients with SLE and OA. Disclosure of Interest: None declared DOI: 10.1136/annrheumdis-2018-eular.4336

\section{AB1300 COMORBIDITIES IN PATIENTS WITH RHEUMATIC DISEASES IN COLOMBIA}

F.M. Cuervo ${ }^{1}$, A. Santos ${ }^{1}$, E.L. Saldarriaga ${ }^{1}$, J.C. Rueda ${ }^{1}$, I. Angarita ${ }^{1}$, I. Peláez ${ }^{2}$, E. Forero ${ }^{3}$, J. Ramirez ${ }^{4}$, C. Toro ${ }^{4}$, J. Londono ${ }^{1} .{ }^{1}$ Grupo de investigación Espondiloartropatias, Universidad de La Sabana-Hospital Militar Central, Chía, Colombia; ${ }^{2}$ Hospital General de México, Ciudad de México, Mexico; ${ }^{3}$ Universidad del Norte, Barranquilla; ${ }^{4}$ Asociación Colombiana de Reumatología, Bogotá, Colombia

Background: Patients with systemic autoimmune conditions often develop concomitant disease contributing to a higher mortality than in the general population. An early diagnosis and treatment is fundamental to improve the life expectancy of this population.

Objectives: The objective of this study was to describe the frequency of comorbidities in patients with rheumatic diseases.

Methods: Based on data from the population studied under the COPCORD strategy, in the prevalence of rheumatic disease in Colombia, the frequency of nonrheumatic diseases in patients with rheumatic diseases was described in 6 cities of Colombia (Bogotá, Medellín, Cali, Barranquilla, Bucaramanga and Cúcuta).

Results: From a total of 4020 individuals, 2274 rheumatic patients were identified.

Sixty nine percent of the Colombian patients with rheumatic disease $(n=1571)$ had some comorbidity. The most frequent was hypertension (HBP) in $20,95 \%$ $(n=330)$, followed by migraine $19,11 \%(n=300)$ and venous insufficiency $17,69 \%$ $(n=278)$. Seventeen percent had any mental disorders, of which, anxiety and depression were the most common $(n=273)$.

Other comorbidities like obesity $(8,1 \%)$, diabetes $(5,85 \%)$, heart disease $(5,79 \%)$ and cerebrovascular disease $(1,99 \%)$ were less common among rheumatic patients. The frequency of cancer was low $1.48 \%(n=23)$. Abstract AB1300 Figure 1

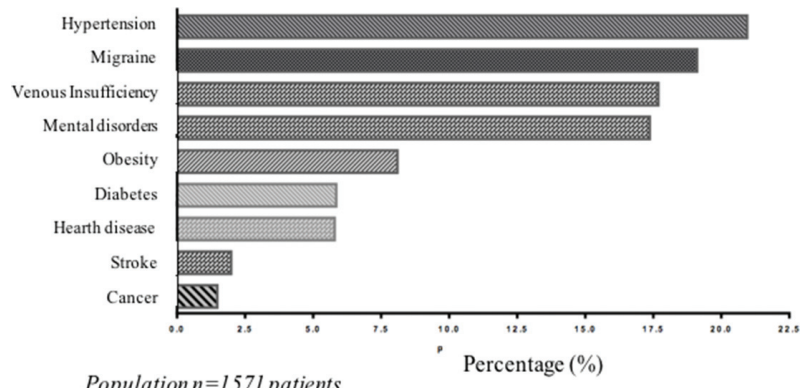

Abstract AB1300 - Figure 1. Most frequent comorbidities in rheumatic patients

Conclusions: Hypertension is the most common comorbidity in patients with rheumatic diseases in Colombia. Screening and diagnosis in early stages of HBP is important, since it is the main modifiable cardiovascular risk factor. The goals of pharmacological and non-pharmacological treatment are essential to reduce the risk of coronary heart disease, stroke and end-stage renal disease. Additionally, migraine is the second most frequent disease that affects the patient's quality of life. And venous insufficiency should be taken into account by primary care physicians in order to assure a complete health care assessment.

Disclosure of Interest: None declared

DOI: 10.1136/annrheumdis-2018-eular.4350 